\title{
New light on the 'cothon' at Motya
}

\author{
B. S. J. ISSERLIN
}

\begin{abstract}
Dr Isserlin, head of the Department of Semitic Studies in the University of Leeds, has been directing excavations in the island of San Pantaleo (Mozia) since I96I. This island is situated in the lagoon that fringes the coast of Sicily to the north of Marsala, and it is the site of the ancient Phoenician city of Motya. Archaeological exploration here goes back to the I8th century, and readers may remember Dr Isserlin's interesting note about Schliemann at Motya in these pages (1968, I44-8). Since I968 Dr Isserlin has been concentrating his work upon the 'cothon' or artificial inner harbour (an example of a type in vogue, according to classical zoriters, among the Phoenicians). Here he discusses his results to date.
\end{abstract}

Recent years have witnessed increasing archaeological activity in the island of San Pantaleo, though for much of what we know we are still indebted to the late Mr J. I. S. Whitaker, who bought the island and carried out important excavations there early in this century.

One of the features of San Pantaleo which attracted Whitaker's attention was a rectangular water-filled basin, the measurements of which he gives as $c .5 \mathrm{I}$ by $37 \mathrm{~m}$. (Whitaker, I92 I, 190), surrounded by ashlar masonry, which is situated near the south-western corner of the island (PL. Xxvil $a$ and FIG. I). When Whitaker first dealt with it, it was linked to the sea by a cutting through soil and seaweed which took up most of a kind of street which led here from the interior of the island to the seashore, across a gap in the town wall. The basin was known as 'La Salinella' and had indeed served as a salt pan during the Middle Ages and after; at times it may also have served as a piscina, or reservoir for fish, particularly during the period of the Jesuit ownership of Mozia from the 16 th to the I 8 th century. Learned visitors to Motya like Schubring ( $1866,6 \mathrm{r}$ ) had noted its existence, and Sicilian antiquarians from the time of Massa onwards were inclined to regard it as a fish pond of Moorish (Arab) construction.

On excavating here, Whitaker discovered that the rectangular basin had in fact been linked to the lagoon by a channel not less than $7 \mathrm{~m}$. wide in any part, $c .3^{\circ} \mathrm{m}$. long, and flanked over part of its course by quays of excellent ashlar masonry. Soundings showed him that the channel was paved over some of its course, and that it had been blocked near its entrance into the lagoon by a transverse wall which he was inclined to ascribe to the time of the great siege to which Motya succumbed in $397 \mathrm{BC}$-when it would have been intended to deny access to the

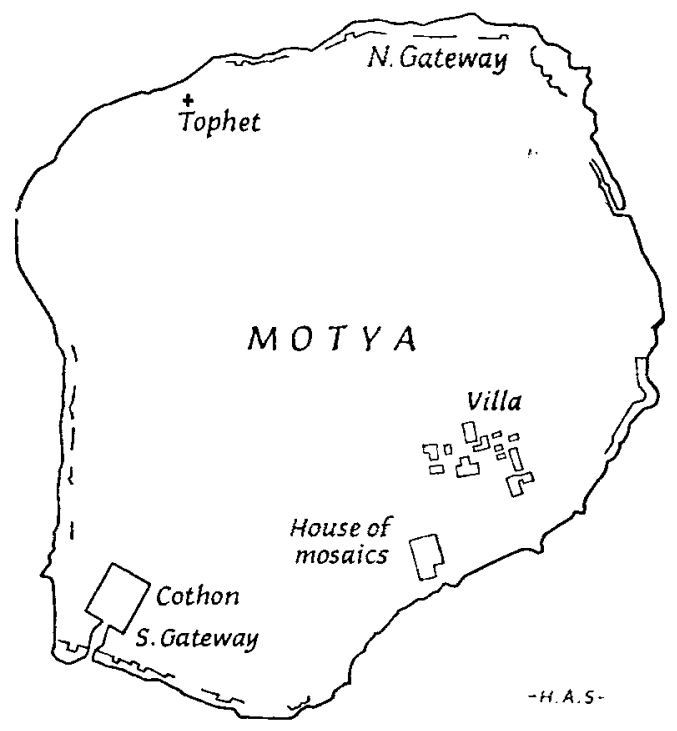

Fig. I. Motya-general map to show location of cothon 


\section{'THE 'COTHON' AT MOTYA}

basin to enemy craft. He interpreted the whole complex of channel and basin as an artificial inner harbour of the type which according to ancient authorities (such as Servius) was in vogue among the Phoenicians and known to them by the name of 'cothon'. The description of his findings, and his interpretation of them, are given in his book (Whitaker, I92I, I85-93). Among reviews of this work, the one by $\mathrm{K}$. Lehmann-Hartleben ( 1926 , col. $182 \mathrm{ff}$.) is of special interest, since he noted that present-day water level in the cothon is higher than it was in antiquity, and that the whole installation has in fact to some extent become flooded. Ocular inspection, and the consideration of other relevant facts such as the flooding of the causeway in ancient times linked Motya with the mainland, tend to support his view. We may assume that the water level in the lagoon, and in the cothon channel and basin linked to the latter, could have risen by $c$. $0.50-1.00 \mathrm{~m}$. since the Phoenician period.

After World War I, Whitaker was unable to continue his excavations at Motya and the investigation of the cothon complex was left incomplete. It was not until 1961 that some additional field work was carried out here by Miss J. du Plat Taylor of the Institute of Archaeology of the University of London, assisted by a team of divers from Imperial College, London led by Mr Brian Matthews, as part of the programme of the Leeds-London expedition of which the present writer was director and Miss du Plat Taylor co-director. Her findings are described in an article (Taylor, I964) which added significant details and modifications to Whitaker's findings, and viewed the resulting picture in the light of the comparative material which had come to hand since his days.

\section{THE EXCAVATIONS OF I 968-I $97^{\circ}$}

The year 1968 witnessed, however, a new approach to the problem of the 'cothon' at Motya. In that year P. Mingazzini contributed an appendix to the report of the Italian expedition which by then had been working for four seasons on the island, entitled 'Scopo e natura del cosidetto Kothon di Mozia' (Mingazzini, 1968, 105-12). In this article, Whitaker's discoveries as modified by Miss du Plat Taylor, and his interpretation of the 'salinella' at Motya as a 'cothon' were made the object of a searching and detailed analysis. He drew attention in particular to the difference in character between the section of the channel nearest to the rectangular basin, and the section between the quay walls: he questioned whether the former had been part of the original scheme, and he also pointed out that the basin seemed ill suited for a port. He accordingly suggested that it might instead have served as a 'sacred lake'part of a sanctuary complex of the kind known in the Phoenician homeland at Amrit.

When Mingazzini's article appeared we were preparing for a fresh study involving both detailed planning and additional excavation of the cothon complex which Whitaker had not been able to reveal completely. Mingazzini's searching questions now seemed to make additional field work even more desirable. This was taken in hand in summer 1968 , and continued in 1969 and 1970 in three brief campaigns.*

*These campaigns were undertaken on behalf of the University of Leeds, with which in I968 Fairleigh Dickinson University, New Jersey, USA, and the Department of Semitic Studies of the University of Sydney, Australia, also associated themselves. (The Head of that Department, Mr E. C. B. MacLaurin, personally participated in the field work.) We are greatly indebted to the daughter of the late excavator, Miss Delia Whitaker, who now owns the island of Motya, for her kind permission to undertake this work, which she has followed with keen interest, and to which she has offered every facility. We also want to express our thanks to the local administrator of the estate, Commendatore Colonello G. Lipari, and also to his son, Signor E. Lipari for their never failing assistance. We have to thank the Antiquities Service of Palermo and its Head, Professor V. Tusa, for support and valuable advice, and similarly the British School in Rome and its Director, Dr John Ward-Perkins, for lending us their assistance and official support. Funds for the excavation were provided partly by the sponsoring Universities and partly by a number of Foundations. Among these we owe a debt of gratitude in particular to the Russell Trust, without whose substantial and continuous support our work at Motya would not have been possible. Other support came from the Stanley Burton Trust, the Leeds Philosophical and Literary Society and the Society of Antiquaries, to all of whom we likewise wish to express our thanks. 


\section{ANTIQUITY}

When we began our work in 1968 Whitaker's old diggings had largely become filled with mud and sand brought in by the sea. We decided to deal with this by mechanical means.*

In r968-9 we managed to excavate the whole of the section of the channel between the masonry quays which had been investigated, and partially freed by Whitaker. It now stands revealed as a splendid piece of marine engineering, constructed from large blocks of sandy limestone, some smooth faced and some provided with marginal draftings and protruding central bosses (PLS. xxvir $b, \operatorname{xxvIII} a$, FIGS. 2-5). The whole structure is divided into three main parts, a narrow central section $(5 \cdot 38 \mathrm{~m}$. across) being preceded to the north and south by sections which widen out, somewhat asymmetrically, towards the lagoon and the basin respectively. The central section in particular possesses a number of interesting features. Its sides are stepped in a way recalling the 'altars' of modern graving docks (cf. the sections, FIG. 5): many of the stones making up these sides are provided with oblong horizontal slots a few centimetres in length, set near the base of the stones. Two triangular buttresses project from the sides at the southern end of this narrowest part of the channel but the walling at the corresponding northern end continues smooth. The top of the eastern quay is marked also by a number of shallow grooves cut into the stone (visible on FIG. 4 and PL. XXVIII $b$ ); these were noted by Miss du Plat Taylor (1964, 92 and 95, fig. 6) and

*A set of Petter pumps held by No. 38 Engineering Regiment in Ripon was made available to us on hire by permission of the British Ministry of Defence (to whom, and to the commanding officer of the Regiment, we beg to express our thanks); together with another pump obtained locally they were set to work under the direction of $\mathrm{Mr} \mathrm{J}$. Fox, a lecturer in the Department of Civil Engineering of Leeds University, assisted by two lance-corporals on leave from the same regiment. After the channel had been closed off from the sea by a wall of sandbags, strong jets of water from the pumps were directed on to the mud surface, turning the solid sandy mud into liquid sludge. This was then pumped out to sea, and the operation repeated until most of the late top deposits had been removed. Following this, the water in the channel and basin was pumped out to sea. Archaeological excavation was thereafter conducted in the normal way, as far as conditions permitted. tentatively explained as intended for the working of some kind of gate or swing bridge.

The central section of the channel is provided with a fine stone pavement placed at a depth averaging $c .1 \cdot 78 \mathrm{~m}$. below the quayside tops (on the sections, FIG. 4 the southern end of the eastern quay is taken as a point of reference with the conventional reading $10.00 \mathrm{~m}$, and levels are referred to this generally hereafter). As PL. xxvina $a$ shows, the paving stones vary in size; some of them have drafted margins and may thus not have been intended from the start for their present function. A noteworthy feature of the paving is a carefully constructed groove, $54 \mathrm{~cm}$. wide and curved in section, which runs along the centre line of the channel. It looks as if this paving had originally continued into the wider northern and southern sections of the part of the channel, but if so it has been robbed out there, and the floor in these sections now consists of the natural clayey tufa (yellow where exposed to the air, but blue below water), into which the whole channel was dug, and which, in the central sector underlies the channel paving. A big stone, now placed at the northern end of the central groove in the pavement as if to act as a stopper, is clearly secondary, and the same is true for two rectangular pillars (one complete and one reduced to a stump) which stand on the mud which has collected in the central groove, just north of the blocking wall which now closes the channel at the place where the buttresses project. These pillars may have supported a bridge constructed across the waterway after it had gone out of use.

About the northern and southern sections of the part of the channel between quays we can be briefer. The southern section is incomplete, the stones near the lagoon having been robbed out, and the question as to how far it continued seawards must await additional exploration. The part splaying out towards the basin, on the other hand, is complete on the western side (the final few stones of the eastern quay have crumbled off and some of these were found in the channel mud). The most noteworthy fact here is that the northern ends of the eastern and western quaysides are topped by rows of roughly finished headers which reach a level 
THE 'COTHON' AT MOTYA

DIDIVI: Quayside paving

Channel paving

-.. Outline of original channel

- Channel as found before excavation

-.....- Line of stones

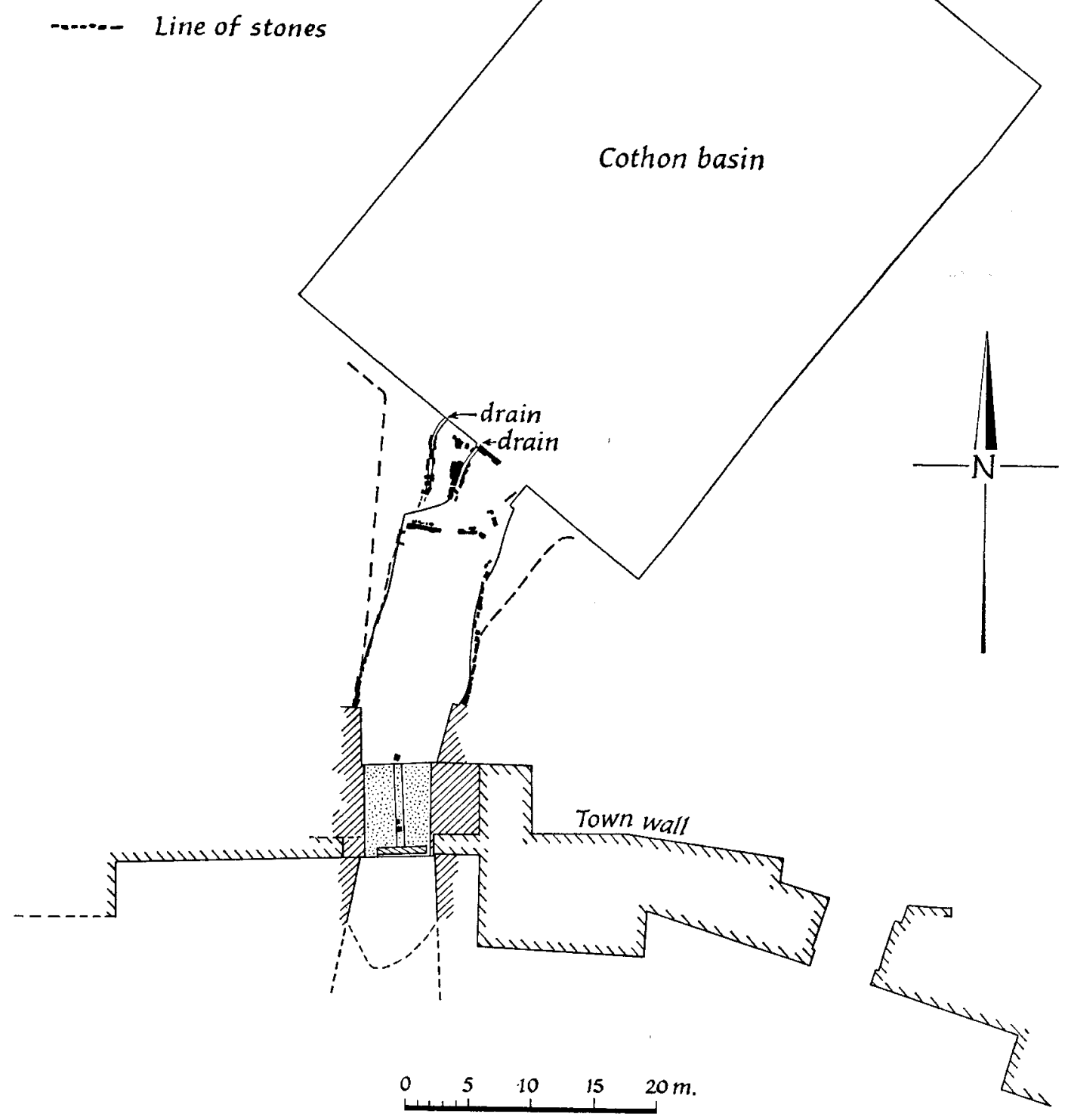

Fig. 2. The cothon basin and channel, general layout

181 


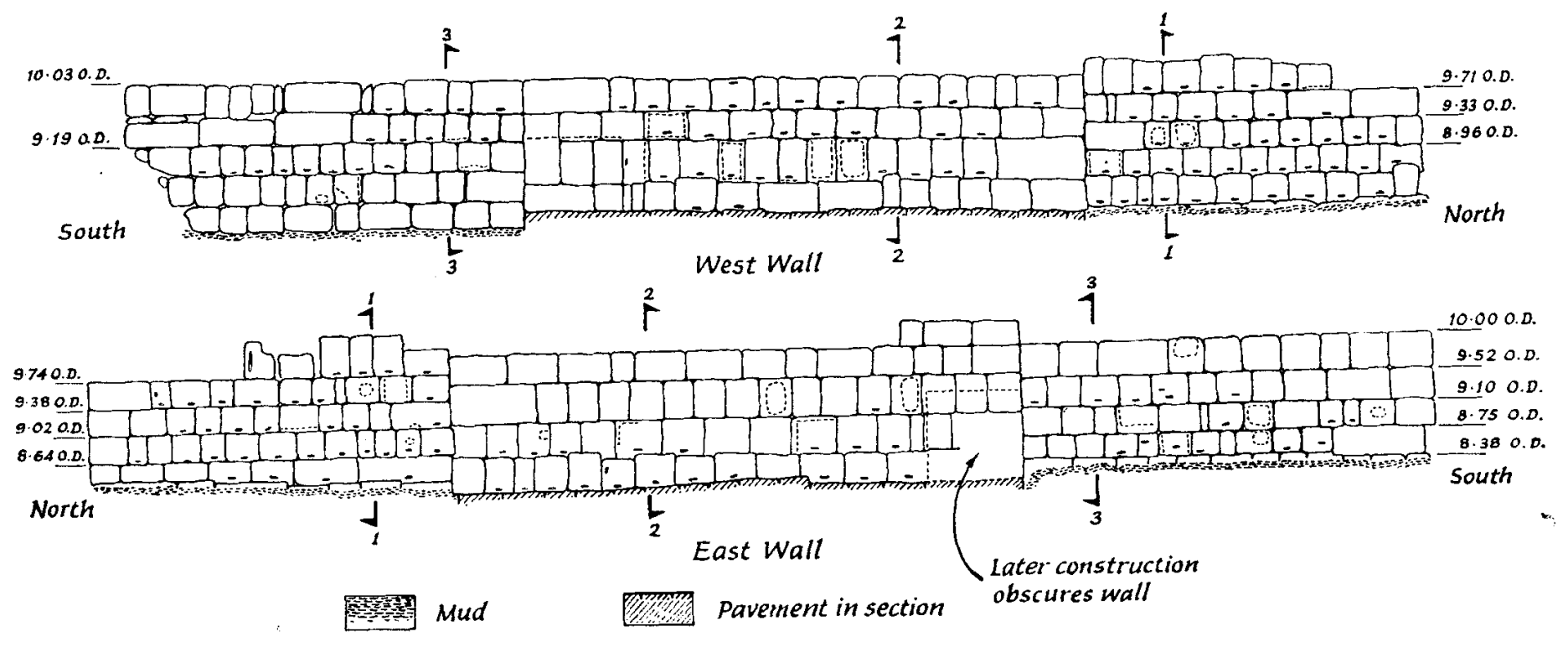

Fig. 3

列
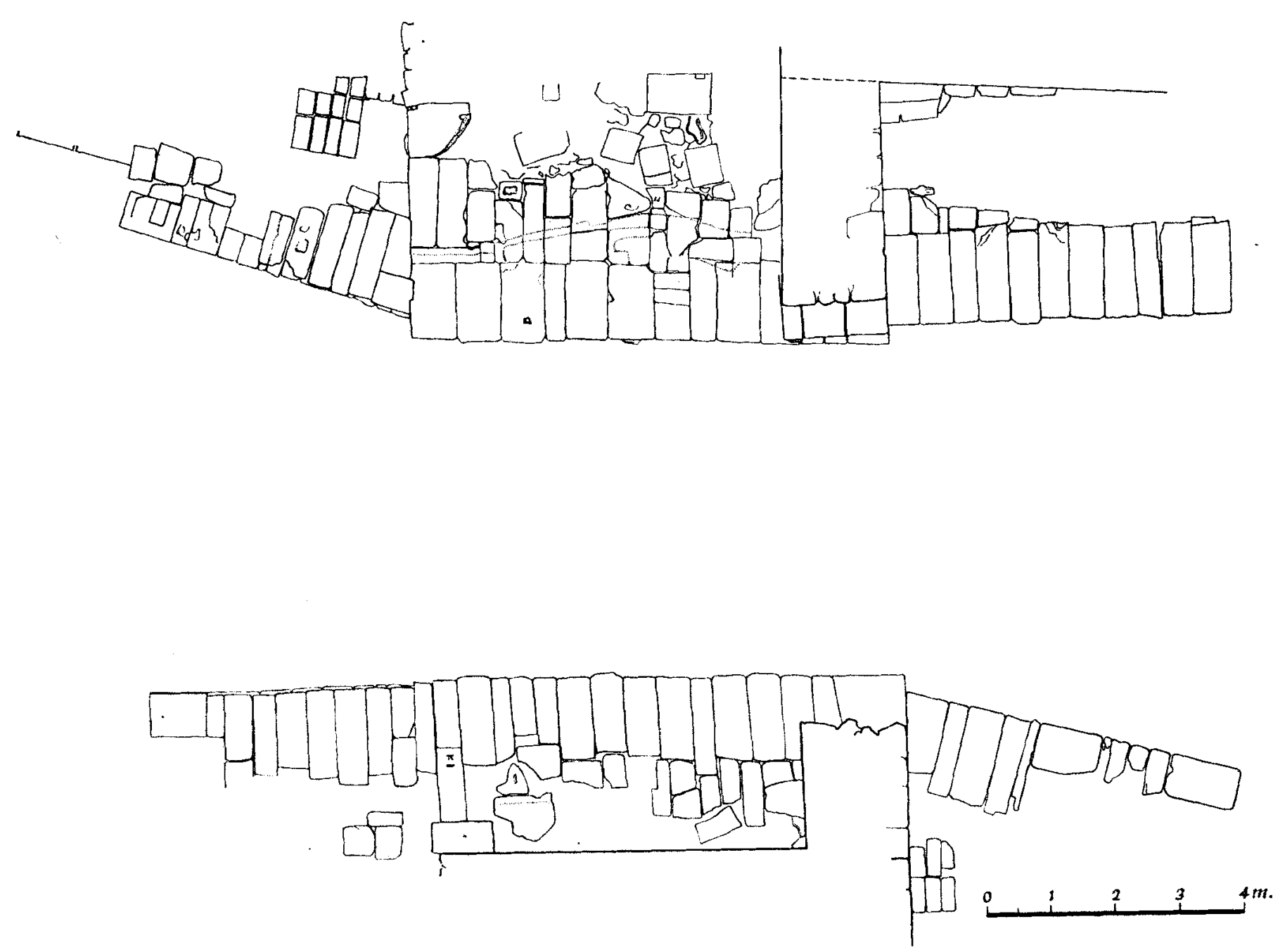

Fig. 4

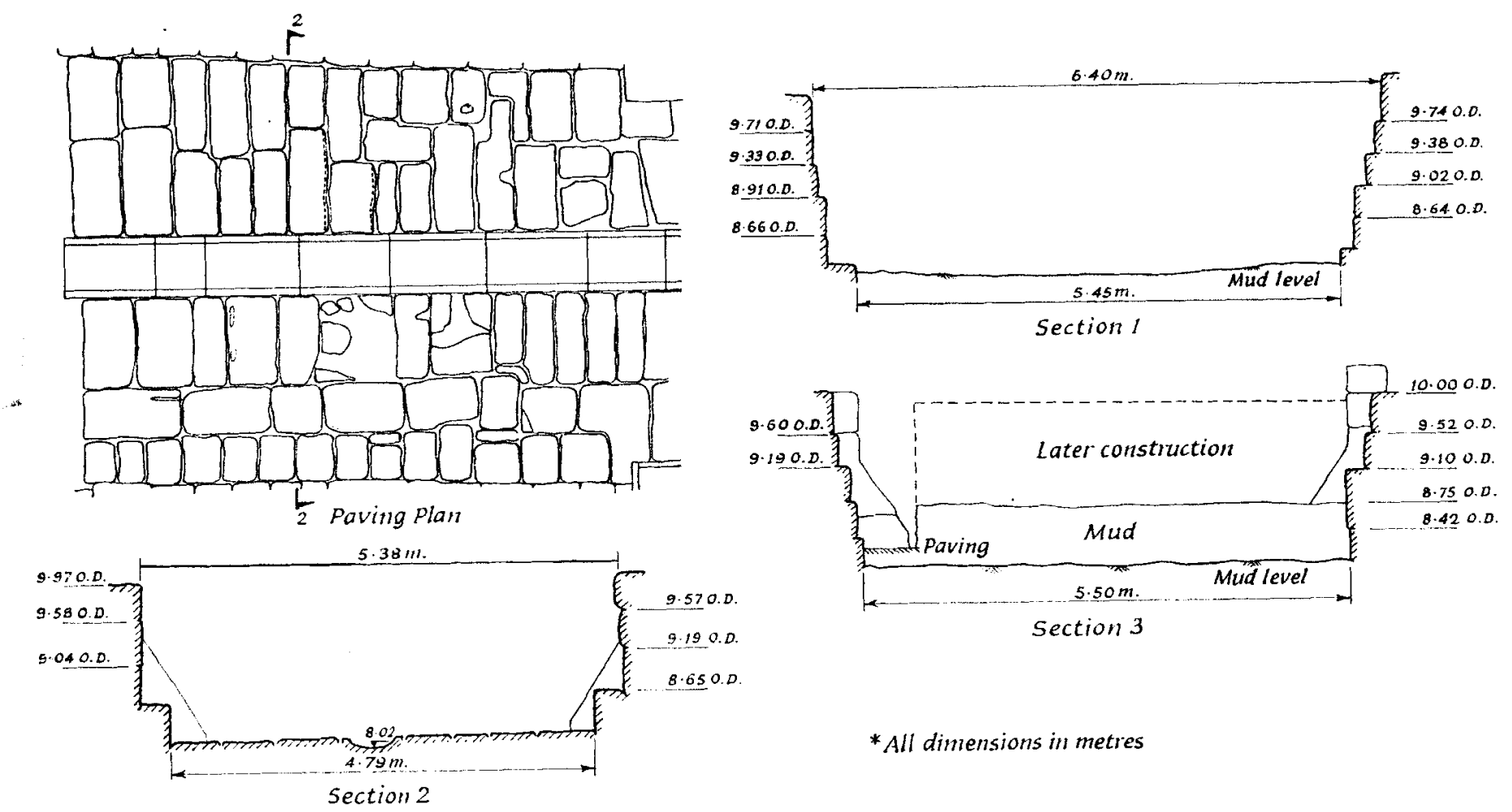

Fig. 5

Section 2

East

West

Fig.7

Fig.7

Captions to figures $3^{-5}$ and 7 above.

Fig. 3. Viezv of eastern and western quays along cothon channel

Fig. 4. Plan of paving on quays flanking the cothon channel

Fig. 5. Plan of cothon channel paving, and sections across channel

Fig. 7. Cothon basin, south wall

Plans of channel and basin and sections by F. and A. Hore, R. Gibbons, W. Horsley and W. Startin 
above that of the adjoining section, and which look as if they might have carried upper masonry of some sort, which has now disappeared. A stone with a ring-shaped groove, found loose in the mud near the northern end of the eastern side, and two brick-shaped holes in the top of the northern extremity of that quay are other features deserving special notice.

\section{INTERPRETATION}

We must now attempt to interpret the installation described above. Whitaker (1921, 192-3) was inclined to think that the quays served for the unloading of goods (passengers would have entered the town through the South Gate nearby); he also thought he detected indications that a gate or drawbridge had originally been placed in a line between the fortification walls either side of the quays, so making it possible to close the channel at this point (ibid,, 19r). The presence of the gate or of a swing bridge was, as we saw, also assumed by Miss du Plat Taylor. Our own findings as outlined in the preceding pages have shown the existence of features normally met in recent graving docks, while others might perhaps recall a canal lock, particularly the existence of a narrow central section approached on each side by a funnel-like construction of the waterway. Neither explanation, however, seems to fit the case completely, as we shall see, even if the differences which may well have existed between modern, and possible ancient practices are taken into consideration.

To deal first with the possible use of the channel section between the quays as a dock. Here there are a number of points in favour. The width of the narrowest section would, as Miss du Plat Taylor has shown (I964, 95), comfortably accommodate an ancient ship with a presumed maximum beam of $4.50 \mathrm{~m}$. Such a ship, on entry, would be guided into position by the lateral buttresses (which are less likely to have been built in order to take the stress generated by the town wall above, since, according to our findings, the latter was extended across the quay walls well after the construction of the quays). The groove in the paving could take the keel, or false keel, of a ship,

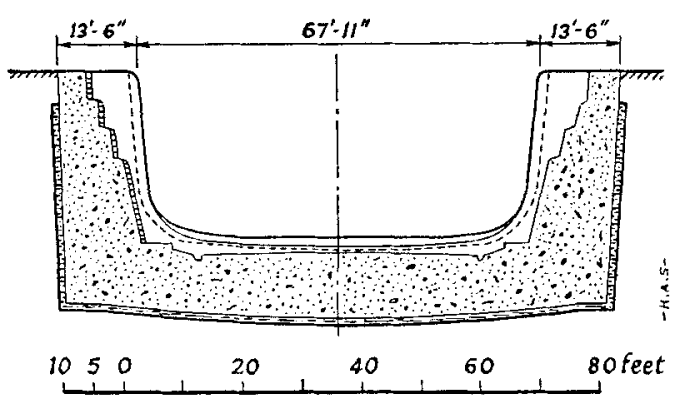

Fig. 6. Section across Albert Dock, London. (From I. F. Vernon-Harcourt, Harbours and Docks, Oxford I 885 ). $80 \mathrm{ft}=24.4 \mathrm{~m}$.

as well as serve for drainage. The altar-like steps in the sides, as well as the slots in the quayside stones could, as in the case of modern practice, be intended to take the ends of timber struts by which a vessel in dock is held upright (cf. the section of a modern dock, FIG. 6). Taking into account the presumed difference between modern and ancient water level, we might assume a medium depth of water in the channel of $c . \mathrm{I} \cdot 00 \mathrm{~m}$., perhaps less. Since there is a slight tide at Motya the minimum water level in the channel would have been such as to incommode the repair or inspection work on strips in the channel very little. If, as Whitaker thought, there was some kind of lock gate at the entrance to the narrowest part of the channel, then low water level could have been maintained as long as desired, and since, on the other hand (as Mr J. Fox pointed out) wave action in a basin connected with the sea by a channel generally tends to build up a higher water level in the basin, a gate mechanism could also have been useful to maintain high water level inside the gate when this seemed desirable. It may also be relevant to refer to the sluicing basins maintained in a number of modern ports (and described e.g. in I. F. Vernon-Harcourt, 1885 , 69): a sudden release of water retained at a higher level could not only have served to float out a ship, but would also have helped to flush the channel clean, and the central groove would presumably have been useful in the evacuation of the water near the pavement level.

At the same time there are a number of diffculties. Two of these apply indeed equally to the 


\section{THE 'COTHON' AT' MOTYA}

possible use of the installation as a dock, and as a canal lock. First, the length of the narrow central section-c. $7.5 \circ \mathrm{m}$.- -is considerably less than the presumed length of a ship (c. $19 \mathrm{~m}$., 'Taylor, 1964, 95) whose width the channel would appear to be intended for. Secondly, if relevant more recent practice is taken as a guide (Vernon-Harcourt, 1882, 438; I885, $8 \mathrm{x}-3)$ then important technical features connected with the gate mechanism in either docks or canal locks are absent at Motya. There are no gate sills (though these might conceivably have been situated to the north and south of the stretch of paving still preserved, and their absence could be due to stone robbing). There are no recesses in the quay walls suitable for accommodating lock gates when folded back. There is no provision for heel posts on which lock gates might have swung - though the gates could conceivably have turned, like ancient gates and doors in general, in pivot stones at the bottom, and in some fittings now disappeared at the top: indeed the stone with the circular groove found loose in the mud and referred to above could have served for such a purpose. It might be argued that the rough ashlar walling laid as stretchers, in the most northerly sections of the two quays, could have carried some kind of superstructure connected with the fitting of gates, and that the shallow grooves cut into the eastern quay paving were perhaps intended to take the ropes or chains by means of which such gates were pulled open or shut. However it is difficult to envisage details at all convincingly. Where the use of the cothon channel as a dock is concerned we must add, furthermore, that there is no indication that the present installation was ever closed off on the landward side, making it into a rectangular basin of the kind to be expected in a graving dock: nor are there any steps down, slides or provision for keel blocks in the present construction. Taking all things together we can perhaps say that the plan and section of the whole installation looks as if graving docks, and possibly basins approached by canals at each end and provided with gates, were known to the builders, but that here they applied their knowledge to a somewhat different scheme. The cothon channel between its quays would have been very useful for unloading a vessel steadied by wooden struts, if the depth of water was sufficient to allow it to enter with a full load: otherwise it could usefully have served to allow inspection and repairs to part of a vessel placed in the central section of the installation. It served in any case as an entrance to the inner channel and basin, which will have to be considered shortly.

\section{THE DATE OF THE INSTAL LATIONS}

Excavations intended to establish the date when the whole installation was built have not yet been completed. In the light of evidence at present available (mainly from test trenches laid against the eastern quay by $\mathrm{Mr} \mathrm{E}$. Oren in I 968 ) it seems that the date of construction should be the end of the 6th century $\mathrm{BC}$, or the early $5^{\text {th. }}$ This would go well with the character of the masonry, which resembles walling from the Phoenician homeland attributable to the Persian period (cf. M. Dunand, I968, 43 and pl. xiii).

It appears that during the final stages in the history of Motya the channel between the quays was no longer properly maintained. We found it covered by a layer of grey mud $c .40 \mathrm{~cm}$. thick and containing numerous potsherds (and a few practically complete vases), and a terracotta mask of Greek type (PL. Xxx). The pottery (not yet fully studied) appears to date from the late $5^{\text {th }}$ century, some of it perhaps to the early 4 th. The blocking wall found by Whitaker was placed on top of this mud, and could thus indeed be attributable to a time very near the end of the city's history. There were practically no finds to be assigned to a time well after the destruction of the city in $397 \mathrm{BC}$ : this could be explained most easily if the channel was filled in at a time not far removed from that event, and indeed the blocking wall might have served to retain such a fill.

To the north of the section between masonry quays, the nature of the ancient channel was until recently unknown. Test trenching during the last three years has shown that it continued northwards, having the same maximum depth (c. $2 \mathrm{~m}$. below quay top-conventional reading $8 \cdot 00$ ) but being contained here by sloping banks cut into the natural tufa. In plan it resembles a 


\section{ANTIQUITY}

funnel widening out so that at the point where it meets the cothon basin it measures $c .17 \mathrm{~m}$. across (cf. the plan, FIG. 2). While a quantity of loose rubble was encountered along the channel sides, there is at present no indication that the banks here were originally lined by walling.

Two lines of irregularly laid ashlar blocks of widely varying kinds and descriptions which now border the channel are in the most southerly part of this sector found halfway up the sloping banks; further north they are superimposed on the mud fill in the channel, and they are thus clearly secondary.

A more detailed consideration of the stratification of this mud fill may prove enlightening.

The bottom deposit in this part of the channel is again grey mud; it contains pottery similar in character and date to that found in the sector between the quays, though there is distinctly less of it; near the junction with the basin there are also a few scattered ashlar blocks. At $c .40 \mathrm{~cm}$. from the bottom, vegetation lines tend to occur, indicating an old mud surface: this corresponds to the level on which the blocking wall further south was founded. Over this there is more grey mud, becoming blackish above, interspersed with lenses of sand. This upper mud is sterile. At $c$. I-I $20 \mathrm{~m}$. from the bottom (conventional reading 9-9.20 m.) more vegetation lines (perhaps indicative of another stage in the filling-up of the channel) occur locally: above this there are layers of sand or sandy grey clay.

It was above these top layers of sand and sandy clay that a number of ashlar blocks delimiting the construction of the northwestern end of the channel, noted by Whitaker and Miss du Plat Taylor, and also two stonelined drains, were found to be placed. All these features are therefore very late: the drains may have served when the basin was used as a salt pan or fish pond. Before this, the ashlar stones irregularly bordering the channel, and also a line of stones across the channel some distance south of its juncture with the basin, were laid on top of the mud fill, at a time when rain wash had partly covered the black channel fill with yellow soil washed down from the yellow tufa of the channel banks. Some of these stones are backed up against this re-deposited material. An earlier stage is marked by the construction of that part of the south wall of the cothon which now completely cuts off the channel from the basin. The foundation packing for this wall is placed into the upper mud: it must thus postdate the construction of the blocking wall across the channel further south, since this was, as we saw, erected above only $40 \mathrm{~cm}$. of bottom mud. However the interval between these two stages need not have been very long. The earliest event in the sequence is the cutting of the channel: this may be attributed to the same time as the construction of the quays or perhaps very slightly before. The second half of the 6 th century $\mathrm{BC}$ would seem to be the time concerned. We found substantial deposits of grey and black mud (which are probably to be explained as a dump of spoil from the cothon channel or basin excavation), below houses of the $5^{\text {th }}$ century $\mathrm{BC}$ in the adjoining area inside the town wall, between the channel and the South Gate. The dump contained pottery from the later part of the 6th century, and this should give the date when the Cothon was dug.

\section{THE COTHON BASIN}

We must now turn to the Cothon basin. In plan, it constitutes a slightly inexactly laid out rectangle--the eastern side curves somewhatbut the overall dimensions may be intended for 35.5 by $c$. $5 \mathrm{I} \mathrm{m}$. as given by Miss du Plat Taylor $(1964,9 \mathrm{r})$. Its sides are orientated in the same way as those of the 'Cappiddazzu' temple further north, and its width (which is also nearly the same as the width of the 'Cappiddazzu' $(35.4 \mathrm{~m})$.$) approximates to those of the actus of$ 120 Attic feet much used in Greek town planning; the length is somewhat less than $1 \frac{1}{2}$ actus. Some element of town planning may thus be implied in the layout.

In its present shape the basin is completely surrounded by masonry, and the south wall (FIG. 7) in particular runs uninterruptedly across the channel entrance, blocking it off completely. The number of courses of ashlar varies from two (part of the eastern wall) to five (near the south-western corner). Here, where the masonry is at its highest level, it reaches almost to the 


\section{THE 'COTHON' AT MOTYA}

same height as the quays bordering the channel $(9.88 \mathrm{~m}$. as against 10.00$)$. The walling at the southern end of the basin is also founded at a level corresponding to that of the channel floor -c. $7.90 \mathrm{~m}$. (but a little deeper in the middle of the south wall where it blocks off the channel entrance). The north wall on the other hand is founded almost a metre higher up-at $c .8 .70 \mathrm{~m}$. -and the foundations of the side walls are likewise mostly laid at higher levels, the bottom course of the south wall being discontinued in each case a short distance after having turned the corners. The topmost layers are locally covered by loosely laid miscellaneous material (evidently due to later repairs). These include part of an Egyptian cavetto cornice placed near the centre of the north side, and part of a moulding in the south side. The masonry proper, below this, also includes stones in secondary use. It is not uniformly laid: the topmost courses are everywhere laid as stretchers, and stretchers also make up most of the lower work in the northern, eastern and southern sides. Near the south-western corner, on the other hand, the lowest three courses are made up of masonry in which headers and stretchers tend to alternate, and which is of much better quality (cf. PL. XXIXa). The lower courses of the northern most part of the west wall also differ in character from the rest of that side. A special feature worth noting is the presence of a ledge, $7.84 \mathrm{~m}$. long and jutting out some $30 \mathrm{~cm}$. from the topmost course, centered somewhat to the east of the middle of the northern wall (PL. $\operatorname{xxIx} b$ ). Flooded at present, this ledge might in antiquity-when the water level was apparently lower-have served as an embarkation point. No proper steps leading down to the water have so far been found anywhere around the basin.

The floor of the basin was found to consist of natural yellow clay or tufa where it was tested; no traces of paving or of any structure inside it have so far been discovered. It slopes gently from north to south, and it is also lower in the middle than at the sides: the foundations of the surrounding walls penetrate very little into it. Deep mud now chokes the whole construction: there is less of this on the eastern side where (as the locals remember), Whitaker removed much mud in his time, but more in the western half. In this western part it may prove possible to establish a stratigraphic sequence in the mud, but this needs further investigation.

\section{CONCLUSIONS}

From trenches sunk against the southern, western, and northern sides of the basin, and from the study of the masonry around the basin, certain conclusions about the history of the whole structure suggest themselves. A test trench placed near the southern end of the western side showed that the foundation trench for the Cothon walling had impinged on pits dateable apparently to the 6th century $\mathrm{BC}$; this provides a terminus a quo for the construction of the basin. The foundation packing behind part of the northern wall, encountered in a test trench near the western end of the projecting ledge, contained sherds attributable to a late stage in the history of the city; this wall should thus have been built in the late $5^{\text {th }}$ or early $4^{\text {th }}$ century BC if not later. Since it forms part of the masonry laid mostly in stretchers, and found chiefly in the upper courses of the walling around the basin, one may suggest that it was then, at a period just before the fall of Motya, or possibly after, that the basin received its present enclosed shape. On the other hand the lower masonry laid in headers and stretchers near the southwest corner, and possibly some other pieces of the lower courses, might date from an earlier stage, perhaps the 6th century BC. Further work must determine these points. It must also in particular be said that, where the south side of the basin is concerned, it is at present impossible to indicate a definite 'plug' of late walling which might have been inserted into a pre-existing open channel-mouth flanked by walling on both sides; the impression gained so far is that except for the western corner, most of the south wall is of one period, even though there is a fairly straight joint running from top to bottom just below the beginning of the western drain.

The picture resulting from all this is as follows: apparently in the 6th century $\mathrm{BC}$ a pre-existing natural depression was converted into a shallow basin, sloping gently southwards, 


\section{ANTIQUITY}

which was locally lined with masonry. This basin communicated with the channel dug to lead from the lagoon. Stratigraphic evidence from the lower part of the trench against the northern side of the cothon, mentioned above, suggests that the shelving muddy shore continued northwards somewhat beyond the limits of the present enclosed 'cothon'. Such a sloping basin would have been very useful for the beaching and careening of ships, and we may suppose that it was intended for careening and other repairs more extensive than the limited facilities in the channel between the quays would allow. This early basin was later enclosed, and made inaccessible to shipping, after the channel had become disused. The date of this transformation is still uncertain, and the purpose of the enclosed pond remains to be determined. There are at present no sufficient signs that it served as a sacred lake (though we must of course remember that later refashionings may have destroyed much evidence). No signs of a sacral peribolos have turned up so far, and the two pieces of architectural mouldings found do not prove the existence of a sanctuary here, though one may have existed not far away.

\section{BIBLIOGRAPHY}

DUNAND, M. 1968. La defense du front méditerranéen de l'Empire Achéménide in (ed.), W. A. Ward, The role of the Phoenicians in the interaction of Mediterranean civilisations, 43-51 (Beirut). LEHMANN-HARTLEBEN, K. 1926. Fahrbuch des Deutschen Archäologischen Instituts, Archäologischer Anzeiger, XLI, cols. I 82-7.

MingazziNI, P. 1968. Scopo e natura del cosidetto Kothon di Motya, in Mozia IV (Rapporto Preliminare della Missione Archeologia della Soprintendenza alle Antichità della Sicilia Occidentale e dell'Università di Roma, Studi Semitici, xxIx, 105-12 (Rome). schubring, J. r866. Motye-Lilybaeum, Philologus, XXIV, 5I-8I.

TAYLoR, J. DU PLAT. 1964. Motya, a Phoenician Settlement in Sicily, Archaeology, xvII, II, 9I-IOO.

VERNON HARCOURT, I. F. 1882. Rivers and Canals (Oxford).

1885. Harbours and Docks (Oxford).

whitaker, J. I. s. I921. Motya, A Phoenician Colony in Sicily (London).

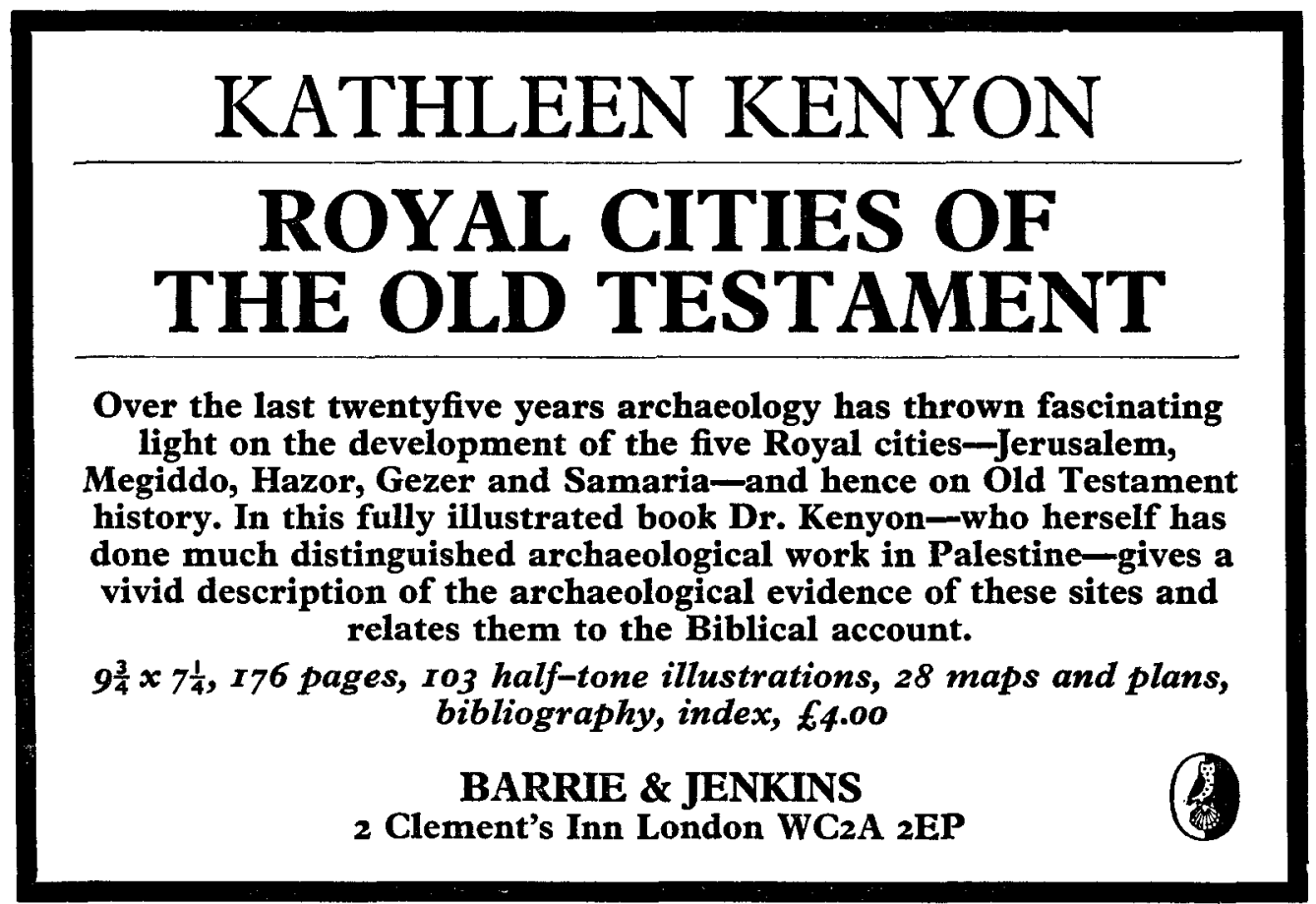




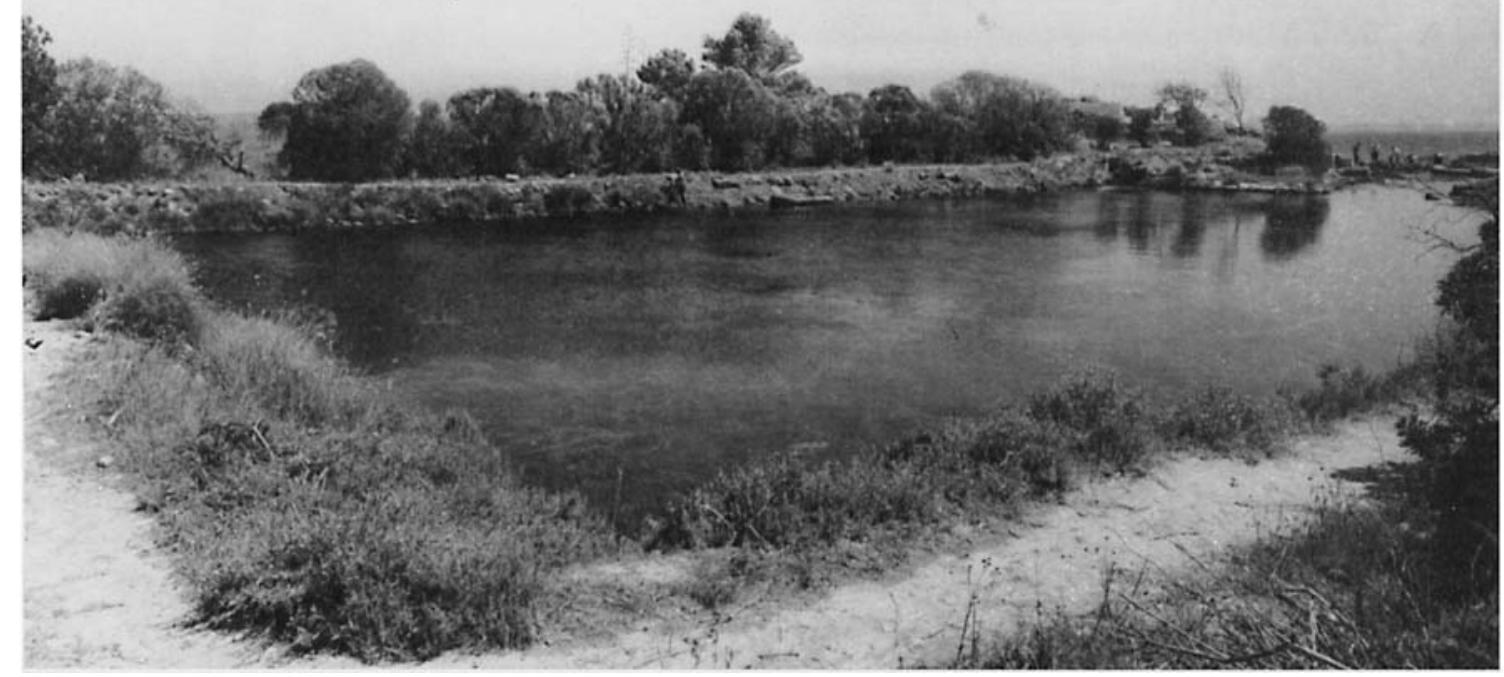

PLATE XXVII: NEW LIGHT ON THE 'COTHON' AT MOTYA

(a) Cothon basin and channel looking $S$ towards the lagoon and Marsala

(b) Channel at the end of the Ig69 excavations, looking N. Note blocking wall on mud above pavement. Unexcavated mud fill is visible in background

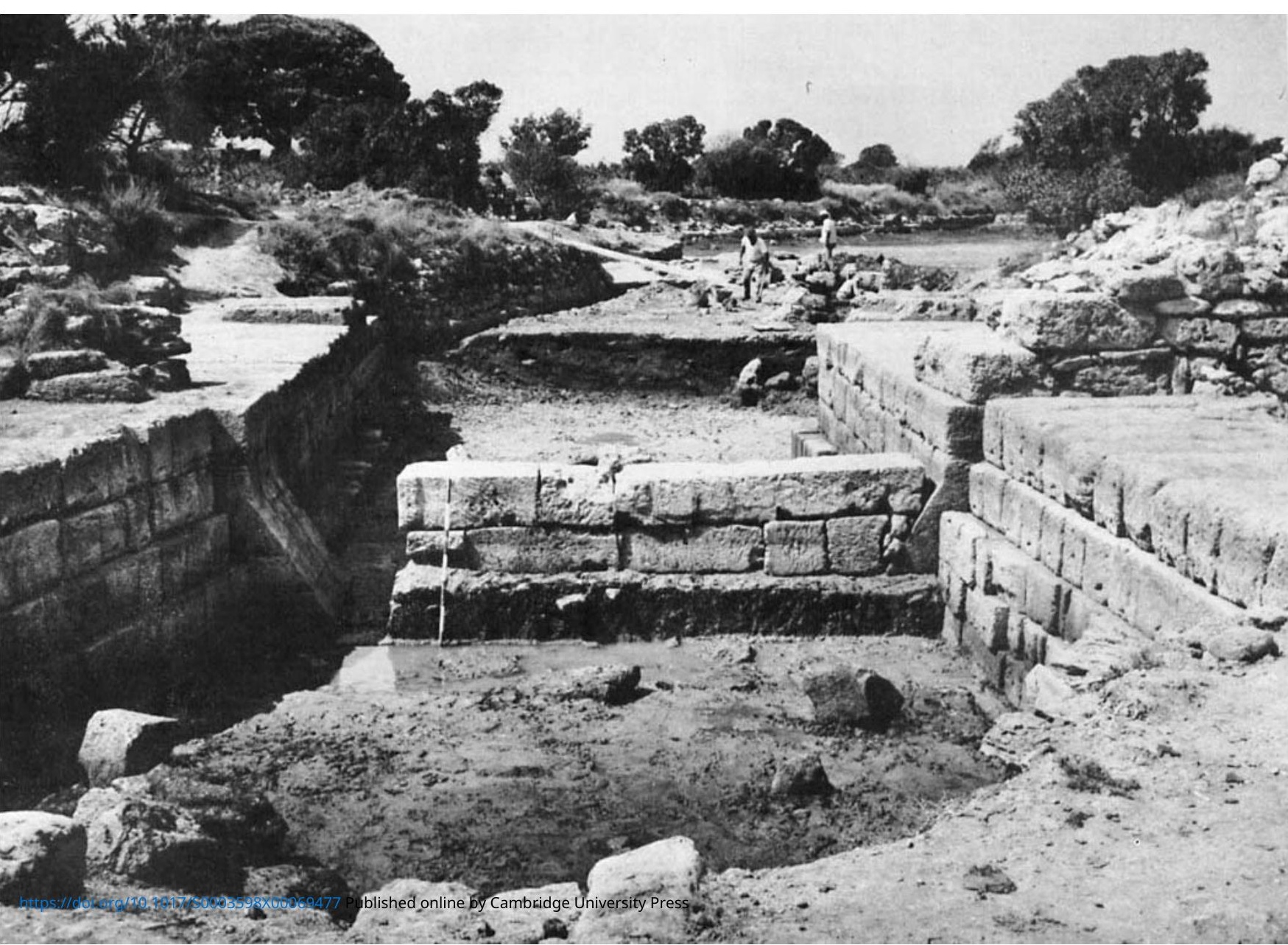




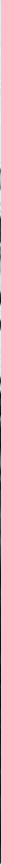

PLATE XXVIII: NEW LIGHT ON THE 'COTHON' AT MOTYA

(a) View of cothon channel at the end of the 1969 excavations, looking S. Note blocking wall built in mud above pavement; the two pillars and the boulder on the pavement are secondary

(b) View of paving on eastern quay with grooves

See pp. 178-86
Photos: a. A. Pegg

b. M. Cookson

$b$

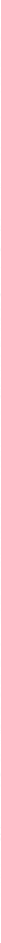



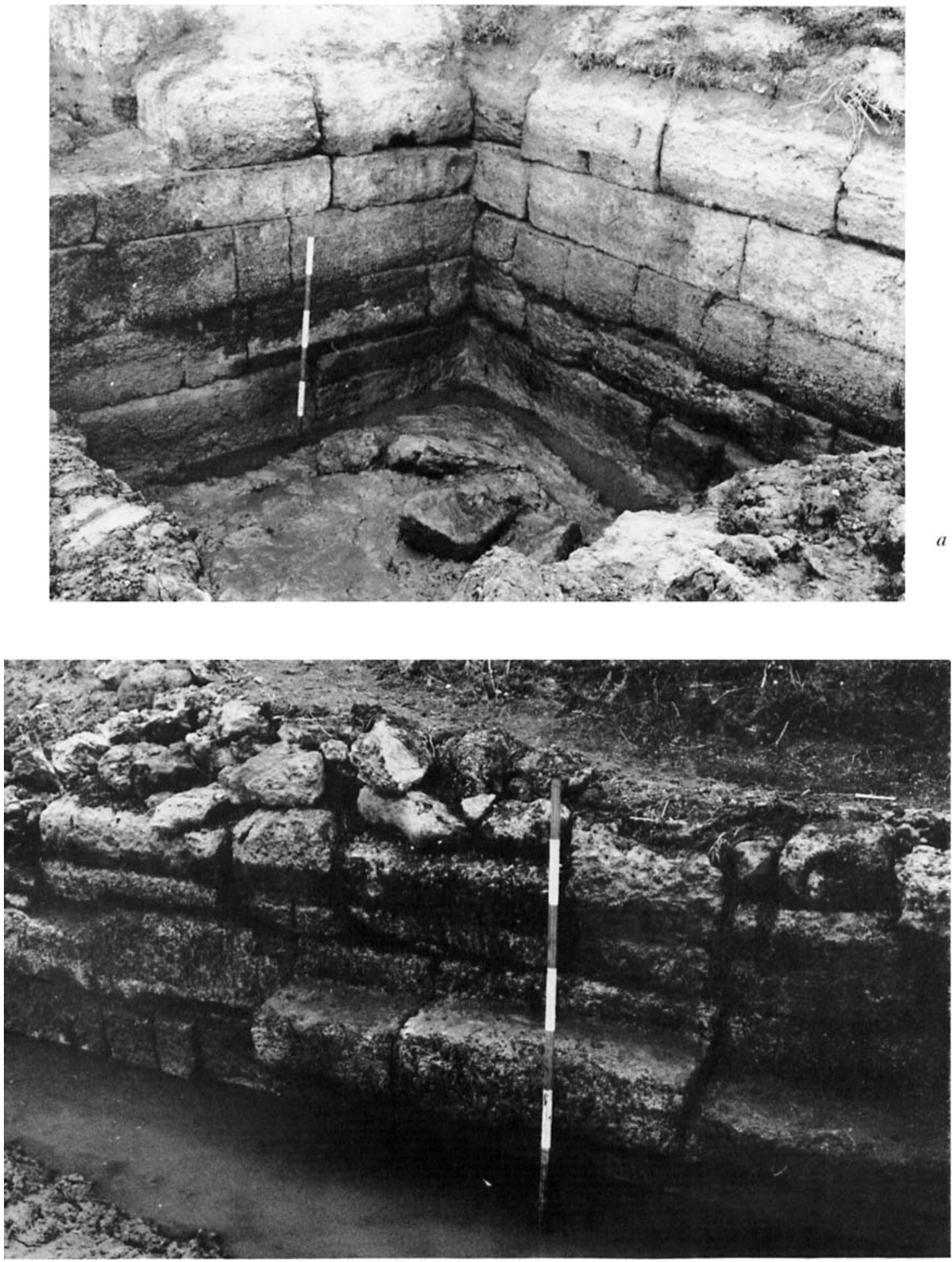

PLATE XXIX: NEW LIGHT ON THE 'COTHON' AT MOTYA

(a) Cothon basin, SW corner, after excavation. Note contrast between topmost three courses with those below (b) Detail of projecting ledge on $N$ side of cothon basin 

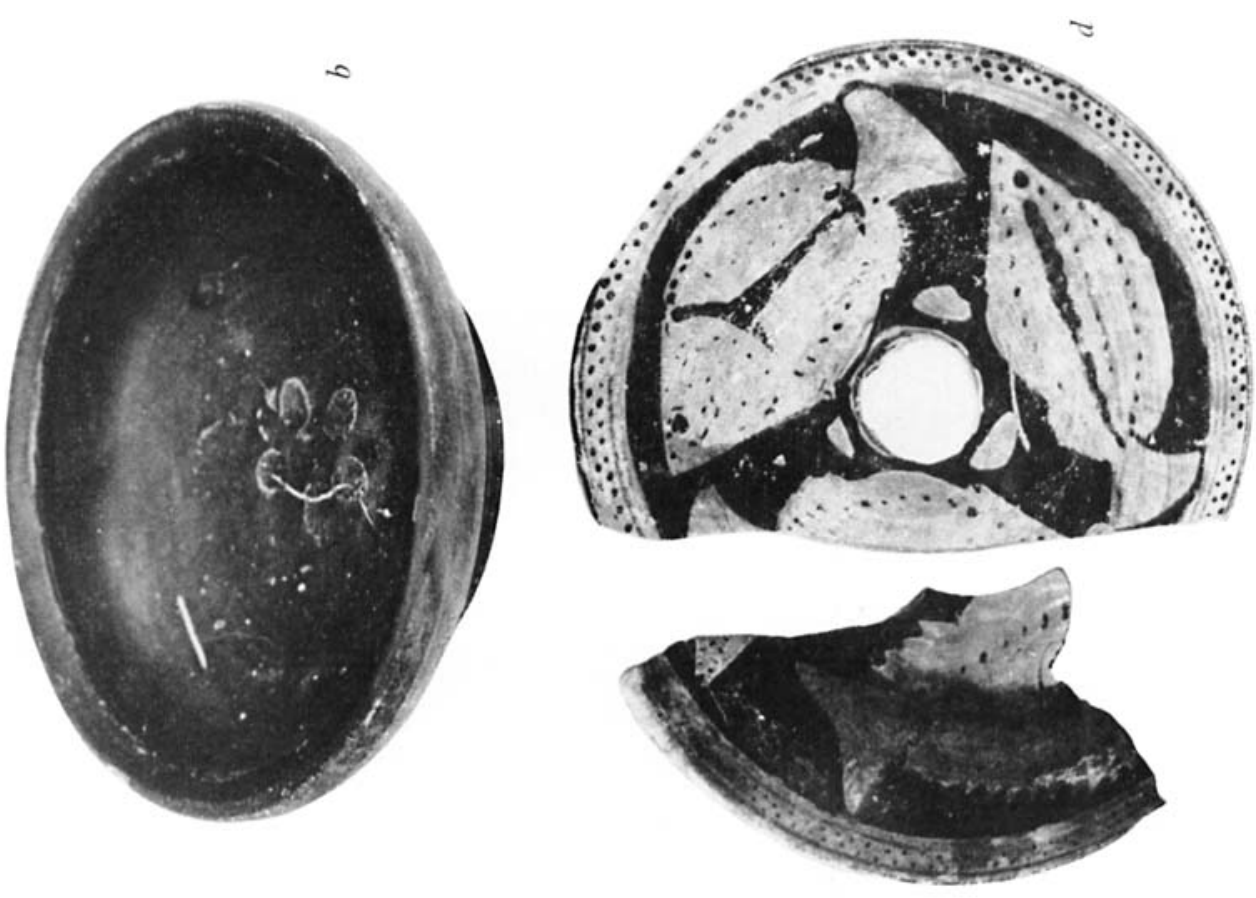

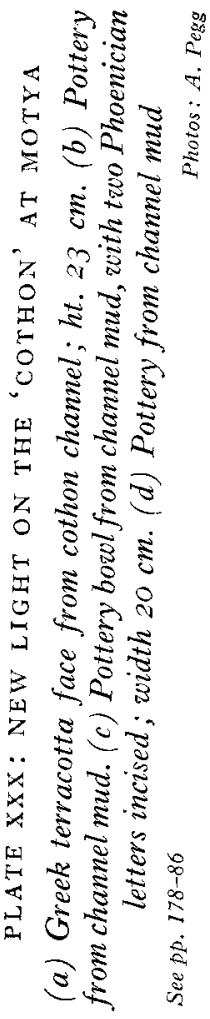
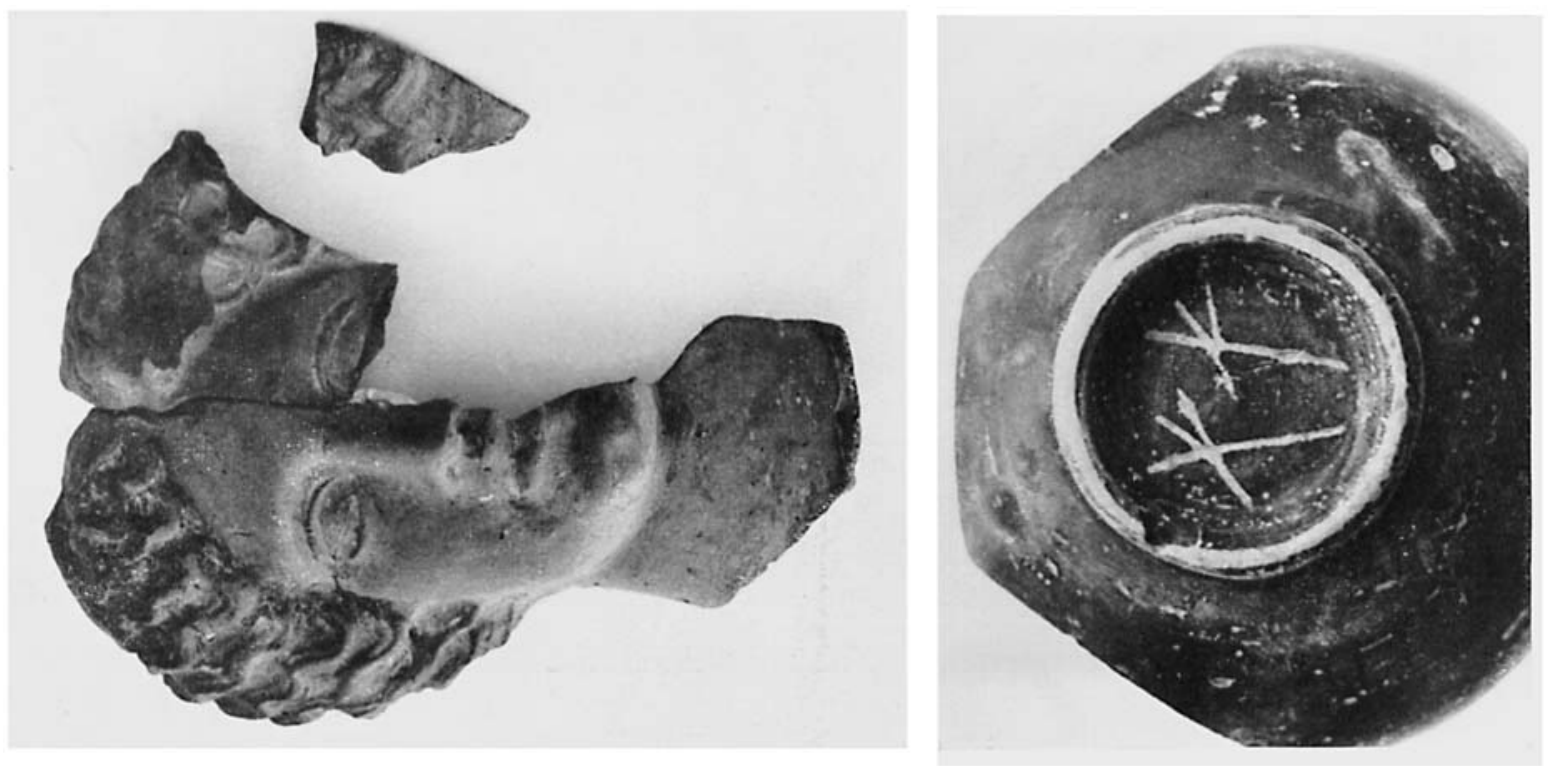